\title{
Complement activation and HLA-B27
}

\author{
SEPPO MERI, ${ }^{1}$ JUKKA PARTANEN ${ }^{2}$ MARJATTA LEIRISALO-REPO ${ }^{3}$ \\ AND HEIKKI REPO
}

From the ${ }^{1}$ Department of Bacteriology and Immunology, University of Helsinki; the ${ }^{2}$ Finnish Red Cross Blood Transfusion Service; and the ${ }^{3}$ Ind Department of Medicine, University Central Hospital of Helsinki, Helsinki, Finland

SUMmARY The efficiency of complement activation was studied in sera from HLA-B27 positive्A and negative subjects (27 with previous yersinia arthritis and 35 controls). Activation of complement with zymosan induced higher mean levels of the anaphylatoxin C3a in HLA-B2خ positive sera (mean (SD) $7.40(1.66) \mathrm{mg} / \mathrm{l})$ than in HLA-B27 negative sera $(6.41(1.79) \mathrm{mg} / \mathrm{l})_{\circ}^{\circ}$ Similarly, higher levels of C3d,g, another C3 breakdown fragment, were obtained in HLA-B2P positive sera after Escherichia coli 0111:B4 lipopolysaccharide treatment $\left(17 \cdot 6(3 \cdot 7) \%\right.$ v $15 \cdot \overrightarrow{q_{3}}$ $(3 \cdot 8) \%)$. The differences occurred irrespective of previous arthritis, complement $\mathrm{C} 4$ or $\mathrm{B}$ phenotype, or variation in background complement levels. The findings suggest that an increasecf responsiveness to complement activators may contribute to the pathogenesis of HLA-B2 associated inflammatory diseases.

Key words: yersinia arthritis, chemotaxis, C4 alleles.

Ankylosing spondylitis ${ }^{12}$ and reactive arthritis after enteric or urogenital infections ${ }^{3}$ are both associated with HLA-B27. Although the mechanism by which the HLA-B27 allele predisposes to disease is unknown, it is possible that HLA-B27 positive subjects are unduly susceptible to mediators of inflammation or they generate them in excess in response to a phlogistic stimulus. ${ }^{4}$ This proposal is supported by the findings that polymorphonuclear leucocytes from HLA-B27 positive patients with reactive yersinia arthritis or ankylosing spondylitis, and from healthy subjects with HLA-B27, show increased chemotaxis in vitro ${ }^{5}$ and in vivo. ${ }^{6}$ It is also in agreement with the clinical observation that inflammatory symptoms are more severe in HLAB27 positive patients with yersinia arthritis than in HLA-B27 negative patients. ${ }^{78}$ The reason for the aberrant polymorphonuclear leucocyte migration is unknown. The finding that after treatment with zymosan polymorphonuclear leucocyte migration in vitro is stimulated more by HLA-B27 positive sera than by HLA-B27 negative sera ${ }^{10}$ suggests that complement derived chemotaxins, such as $\mathrm{C5a}$, may

Accepted for publication 15 August 1987.

Correspondence to Dr Seppo Meri, Department of Bacteriology and Immunology, University of Helsinki, Haartmaninkatu 3, 00290 Helsinki, Finland. play a part. This prompted us to study whethe? activation of complement is, in itself, aberrant in $\overrightarrow{\overrightarrow{0}}$ sera from patients with previous yersinia arthritis and healthy subjects with HLA-B27.

\section{Subjects and methods}

S U B JE C TS

Thirty HLA-B27 positive subjects (20 women, 10 . men), aged $23-55$ (mean 40.5 years) and 32 HLA@ B27 negative individuals (28 women, four men), aged $30-59$ (mean $44 \cdot 3$ years) were studied. Sixteers (nine women and seven men) of the HLA-B27 positive subjects and 11 (nine women and two men? of the HLA-B27 negative subjects had hadu clinically ${ }^{11}$ and serologically ${ }^{8}$ recorded yersinia arthritis six to 15 (mean 10) years earlier. The HLA-B27 positive (11 women and three men) ando negative (19 women and two men) controls were healthy laboratory staff and hospital personnel. The patients were followed up at the outpatient depart ment of the University Central Hospital of Helsinki:At the time of venipuncture no patient had arthritis though four complained of mild arthralgia o\$ peripheral joints. Seven patients had occasionall\$ experienced low back pain, and one of 20 patients had radiological evidence for sacroiliitis. The meap erythrocyte sedimentation rate was $11 \mathrm{~mm} / \mathrm{h}$ (ranges 
2-28). C reactive protein levels were normal $(<8 \mathrm{mg} / \mathrm{l})$ in all patients.

\section{S A M P LES}

Fresh serum and ethylenediaminetetra-acetate (EDTA) (0.01 M) plasma samples were obtained from all subjects and stored in aliquots at $-70^{\circ} \mathrm{C}$ for no more than three weeks before anaphylatoxin studies and for about two months before C3d,g assays.

\section{HLA AND COMPLEMENT TYPING}

HLA typing was performed using several antisera to 30 HLA A, B and C antigens. C4 and Bf allotypes were determined by immunofixation electrophoresis of EDTA plasma samples. ${ }^{12} 13$ Nomenclature was used only for well defined C4 allotypes. ${ }^{14} 15$

\section{COMPLEMENT DETERMINATIONS}

Serum C3, C4, and factor B levels were assayed by radial immunodiffusion (Behringwerke, Marburg, FRG) and the haemolytic complement titre $\left(\mathrm{CH}_{50}\right)$ by Mayer's tube haemolysis assay. ${ }^{16}$ Complement activation products, C3a and C5a, were assayed as C3 desArg and C5a desArg by a competitive radioimmunoassay developed by Hugli and Chenoweth $^{17}$ (Upjohn Diagnostics, Kalamazoo, Michigan, USA). C3d,g levels were determined by radial immunodiffusion after precipitation with polyethylene glycol, ${ }^{18}$ and the results are expressed as a percentage of a maximally zymosan activated ( 5 $\mathrm{mg} / \mathrm{ml}$, six hours at $37^{\circ} \mathrm{C}$ ) standard. To activate complement in sample sera equal volumes $(200 \mu \mathrm{l})$ of serum and zymosan in phosphate buffered saline (PBS, $0.01 \mathrm{mg} / \mathrm{ml}$ for $\mathrm{C} 3 \mathrm{a}$ and $0.3 \mathrm{mg} / \mathrm{ml}$ for C5a), or $E$ coli 0111:B4 lipopolysaccharide (Difco Laboratories, Detroit, Michigan, USA) $2 \mathrm{mg} / \mathrm{ml}$, or a suspension of Yersinia enterocolitica 0:3 isolate (approximately $10^{10}$ bacteria/ml), were mixed and incubated for $30 \mathrm{~min}$ at $37^{\circ} \mathrm{C}$. The reaction was stopped by addition of $200 \mu \mathrm{l}$ of ice cold EDTA $(0.02 \mathrm{M})$ in PBS. To remove natural antizymosan antibodies from sample sera a zymosan absorption procedure was carried out by incubating sera at $4^{\circ} \mathrm{C}$ overnight with $2 \mathrm{mg} / \mathrm{ml}$ (final concentration) of zymosan. After centrifugation supernatants were activated as above, and the anaphylatoxin levels were determined.

\section{STATISTICAL ANALYSIS}

Statistical comparison of mean values was by Student's $t$ test. The results were analysed to determine HLA specificities other than HLA-B27, and corrected $p$ values were determined by multiplying each $p$ value by 30 . The equality of variances was tested with the $F$ test, and, when necessary, the Welch's correction was used.

\section{Results}

GENERATION OF COMPLEMENT ANA PHYLATOXINS

Activation of complement in sample sera with zymosan led to about a 100 -fold increase in levels of C3a desArg. The mean level of C3a desArg was higher $(\mathrm{p}<0.05)$ in HLA-B27 positive activated sera than in HLA-B27 negative sera (Table 1). The corresponding difference between healthy subjects and patients with previous yersinia arthritis was not significant $(6.69(1.51) \vee 7.13(2.05) \mathrm{mg} / \mathrm{l}$ respectively, $p>0 \cdot 05$ ). In fresh non-activated sera the levels of $\mathrm{C} 3 \mathrm{a}$ desArg did not differ between the groups and the levels of C5a desArg were below the detection limit of the assay. In zymosan activated absorbed (with zymosan) sera C5a desArg values

Table 1 Complement anaphylatoxin levels in sera from HLA-B27 positive and negative subjects with previous yersinia arthritis and healthy controls after activation with zymosan*

\begin{tabular}{|c|c|c|c|c|c|c|}
\hline \multirow[t]{2}{*}{ Parameter } & \multicolumn{2}{|l|}{ All subjects } & \multicolumn{2}{|c|}{$\begin{array}{l}\text { Subjects with } \\
\text { previous yersinia arthritis }\end{array}$} & \multicolumn{2}{|c|}{ Healthy controls } \\
\hline & $\begin{array}{l}B 27^{+} \\
(n=30)\end{array}$ & $\begin{array}{l}B 27^{-} \\
(n=32)\end{array}$ & $\begin{array}{l}B 27^{+} \\
(n=16)\end{array}$ & $\begin{array}{l}B 27^{-} \\
(n=11)\end{array}$ & $\begin{array}{l}B 27^{+} \\
(n=14)\end{array}$ & $\begin{array}{l}B 27^{-} \\
(n=21)\end{array}$ \\
\hline \multirow{6}{*}{$\begin{array}{l}\text { C3a desArg in } \\
\text { Non-activated sera ( } \mu \text { g/l) } \\
\text { Zymosan activated sera } \\
\text { (mg/l) } \\
\text { C5a desArg ( } \mu \text { g/l) in } \\
\text { Zymosan activated sera } \\
\text { Zymosan activated } \\
\text { absorbed sera }\end{array}$} & & & & & & \\
\hline & $74 \cdot 1(16 \cdot 9)$ & $72 \cdot 8(19 \cdot 4)$ & $72 \cdot 2(17 \cdot 5)$ & $80 \cdot 5(16 \cdot 1)$ & $71 \cdot 4(16 \cdot 5)$ & $68 \cdot 8(21 \cdot 1)$ \\
\hline & $7.40(1.66) \dagger$ & $6.41(1.79)$ & $7 \cdot 38(1.77)$ & $6.78(2.40)$ & $7.39(1.64) \dagger$ & $6.22(1.41)$ \\
\hline & & & & & & \\
\hline & $701(166)$ & $641(131)$ & $731(135) \dagger$ & $616(125)$ & $671(185)$ & $653(134)$ \\
\hline & $329(246) \dagger$ & 202 (113) & 339 (259) & $250(164)$ & $321(235) \ddagger$ & 177 (87) \\
\hline
\end{tabular}

${ }^{*}$ Results are given as mean (SD).

$t \mathrm{p}<0 \cdot 05$, comparison with respective $\mathrm{B} 27^{-}$groups.

$\ddagger \mathrm{p}<0 \cdot 01$. 
Table 2 Complement C3d,g levels in sera from HLA-B27 positive and negative subjects with previous yersinia arthritis and healthy controls after activation with E coli 0111:B4 lipopolysaccharide (LPS) or Yersinia enterocolitica 0:3

\begin{tabular}{|c|c|c|c|c|c|c|}
\hline \multirow[t]{2}{*}{ Parameter } & \multicolumn{2}{|l|}{ All subjects } & \multicolumn{2}{|c|}{$\begin{array}{l}\text { Subjects with } \\
\text { previous yersinia arthritis }\end{array}$} & \multicolumn{2}{|c|}{ Healthy controls } \\
\hline & $\begin{array}{l}B 27^{+} \\
(n=30)\end{array}$ & $\begin{array}{l}B 27^{-} \\
(n=32)\end{array}$ & $\begin{array}{l}B 27^{+} \\
(n=16)\end{array}$ & $\begin{array}{l}B 27^{-} \\
(n=11)\end{array}$ & $\begin{array}{l}B 27^{+} \\
(n=14)\end{array}$ & $\begin{array}{l}B 27^{-} \\
(n=21)\end{array}$ \\
\hline \multicolumn{7}{|c|}{$\begin{array}{l}\text { C3d,g (\%) in sera activated } \\
\text { with }\end{array}$} \\
\hline E coli 0111:B4 LPS & $17 \cdot 6(3 \cdot 7) \ddagger$ & $15 \cdot 0(3 \cdot 8)$ & $18 \cdot 4(3 \cdot 7) \ddagger$ & $13 \cdot 6(2 \cdot 4)$ & $17 \cdot 0(3 \cdot 7)$ & $15 \cdot 8(4 \cdot 5)$ \\
\hline$Y$ entercolitica $0: 3$ & $18 \cdot 8(3 \cdot 1) \dagger$ & $16.8(2.9)$ & $20 \cdot 3(3 \cdot 5)$ & $18.0(2 \cdot 4)$ & $17.5(2.8)$ & $16 \cdot 1(3 \cdot 1)$ \\
\hline \multicolumn{7}{|c|}{$\begin{array}{l}\text { *Mean (SD). Values are expressed as a percentage of standard (maximally activated normal serum). } \\
+\mathrm{p}<0.05 \text {. } \\
\neq \mathrm{p}<0.01\end{array}$} \\
\hline
\end{tabular}

were higher in HLA-B27 positive sera (Table 1). In non-absorbed sera a difference in C5a desArg levels was also seen, but it was not statistically significant.

GENERATION OF C $3 \mathrm{~d}, \mathrm{~g}$

In light of the potential significance of the above results the experiments were repeated with $\mathrm{C} 3 \mathrm{~d}, \mathrm{~g}$ as an index of complement activation and $E$ coli lipopolysaccharide and cells of $Y$ enterocolitica as complement activators. Thus when patients and controls were considered together significant differences in C3d,g levels were observed between HLA-B27 positive and negative groups after activation with either of the two activators (Table 2). After activation with $E$ coli lipopolysaccharide no significant difference was seen between patients with previous yersinia arthritis and healthy subjects, whereas after activation with $Y$ enterocolitica higher C3d,g levels were observed in the former group $(19.3(3.0) \% \vee 16.7(3.0) \%$ respectively, $\mathrm{p}<0.05)$.

\section{COMPLEMENT LEVELS}

A comparison of HLA-B27 positive and negative fresh sera before activation showed no significant difference in the levels of C3 (863 (120) $v 865$ (131) $\mathrm{mg} / 1$, mean (SD)), C4 (364 (92) v 357 (105) mg/l), factor $\mathrm{B}(172(45) v 170(46) \mathrm{mg} / \mathrm{l})$ or $\mathrm{CH}_{50}$ activity $(37.3(9.5) v 36.8(7 \cdot 1) \mathrm{IU} / \mathrm{ml})$. Moreover, the distribution of $\mathrm{C} 4$ and factor $\mathrm{B}$ alleles did not differ between these groups (data not shown).

H L A - B 8

Analysis of the results in respect of class I major histocompatibility antigens other than HLA-B27 showed that HLA-B8 positive subjects $(n=12)$ had a lower mean level of C3a desArg in activated sera than HLA-B8 negative subjects $(\mathrm{n}=35)(5.59(1 \cdot 11)$ $v 7.25(2.10) \mathrm{mg} / \mathrm{l}$, corrected $\mathrm{p}<0.05)$; nine of the
HLA-B8 positive subjects did not have HLA-B27, and their C3a desArg level was $5.26(1.20) \mathrm{mg} / \mathrm{a}$ (corrected $\mathrm{p}<0.05$ ).

\section{C4 PHENOTYPES}

Analysis of the $\mathrm{C} 4$ phenotypes with respect to ${ }^{\infty}$ disease indicated that the prevalence of the $\mathrm{C} 4 \mathrm{AQO}$ ('null') allele was $29 \%(6 / 21)$ in patients with previous yersinia arthritis and $40 \%(4 / 10)$ in those⿳亠二口犬 patients who were HLA-B27 negative comparedo with $19 \%(5 / 27)$ in healthy controls. In a group of 254 healthy Finnish blood donors prevalence of the C4A null allele was $22 \%$.

\section{Discussion}

The results of the present study show that activatione of complement with zymosan, $E$ coli lipopolysaccharide, or $Y$ enterocolitica tends to lead to highet levels of complement derived activation products in HLA-B27 positive sera than in HLA-B27 negative sera. No major complement abnormality was associ은 ated with HLA-B27 despite the genetic linkage of the HLA-B locus to the major histocompatibilitye. complex class III complement genes ('complementw activation locus'). A slightly increased prevalence of the C4A null allele $(40 \% v 20 \%$ in general population) was observed in HLA-B27 negative subjects with a history of reactive arthritis.

The reasons for the differences in the complemento activation responses between HLA-B27 positive and negative sera are unknown. Increased levels of ${ }^{?}$ complement components, and consequently of the activation fragments, may occur during the 'acute phase response'. This is, however, an unlikely? explanation because the levels of $\mathrm{C} 3, \mathrm{C} 4$, factor $\mathrm{B}, \mathbb{2}$ and $C$ reactive protein were not increased ing HLA-B27 positive sera. During an actual inflamma- 
tory process the situation could be different as changes in complement activity possibly reflect the degree of inflammation.

Specific IgG class antibodies have been shown to augment formation of the alternative pathway $\mathrm{C} 3$ convertase and thereby to enhance complement activation. ${ }^{19}$ Higher levels of such antibodies in HLA-B27 positive sera could lead to increased complement activation. The fact that after absorption of these antibodies significantly higher C5a desArg levels could still be generated in HLA-B27 positive sera than in HLA-B27 negative sera, makes this explanation unlikely. In the case of complement activation by cells of $Y$ enterocolitica (which may be inhibited by the expression of a virulence plasmid ${ }^{20}$ ) the higher $\mathrm{C} 3 \mathrm{~d}, \mathrm{~g}$ response in the patient group is possibly due to enhancement by antibody mediated complement activation as the patient sera apparently contained anti-yersinia antibodies more frequently than did the control sera. Still, this does not explain the observation that $\mathrm{C} 3 \mathrm{~d}, \mathrm{~g}$ levels were higher also in HLA-B27 positive subjects.

The presence of different amounts of complement activating factors, such as endotoxin, immune complexes, increased proteolytic or C3 convertase, stabilising activity in sample sera may provide an explanation. In fresh EDTA plasmas, however, there was no significant difference in the background $\mathrm{C} 3 \mathrm{a}$ desArg levels, suggesting that complement activation may not have occurred in vivo. Finally, it may be that an aberration in the regulation of complement activation exists in HLA-B27 positive sera. This could lead to an exaggerated function of the alternative or classical pathway C3 convertases in the presence of a suitable target.

An increased tendency to generate the oligopeptides $\mathrm{C} 3 \mathrm{a}$ and $\mathrm{C} 5 \mathrm{a}$ may play an important part in HLA-B27 associated diseases and provides a possible explanation for the previously observed increased neutrophil migration ${ }^{69}$ and inflammatory symptoms $^{8}$ in HLA-B27 positive patients with yersinia arthritis. C3a increases vascular permeability by releasing histamine from mast cells. ${ }^{21}$ Binding of C5a by specific cell surface receptors ${ }^{22}$ is responsible for several events in neutrophils such as adherence, ${ }^{23}$ chemotactic and chemokinetic migration, ${ }^{24}$ activation of the respiratory burst, ${ }^{25}$ release of lysosomal enzymes, ${ }^{26}$ and production of leucotrienes with chemotactic or microvascular permeability (or both) increasing activities. ${ }^{27}$

The prevalence of HLA-B8 is decreased in patients with ankylosing spondylitis. ${ }^{28}$ We found low levels of C3a desArg in HLA-B8 positive, zymosan treated sera. It is tempting to propose that a low anaphylatoxin response protects against the development of ankylosing spondylitis, whereas enhanced efficiency of complement activation, e.g., in response to endotoxin released from the gut or persisting in tissues, contributes to the development of ankylosing spondylitis or reactive arthritis.

Increased efficiency of complement activation may thus be one of the factors affecting disease expression and severity of inflammation in patients with HLA-B27 associated diseases.

We thank Ms Tuija Kutvonen and Ms Eine Virolainen for technical assistance, Ms Eeva Kuusalo for secretarial work, and patients and blood donors for serum and plasma samples. This study was supported by grants from the Finnish Cultural Foundation and the Academy of Finland.

\section{References}

1 Brewerton D A. Caffrey M. Hart F D. James D C O. Nicholls A. Sturrock R D. Ankylosing spondylitis and HLA 27. Lancet 1973; i: $904-7$.

2 Schlosstein L, Terasaki P I. Bluestone R, Pearson C M. High association of HLA antigen W27 with ankylosing spondylitis. $N$ Engl J Med 1973; 288: 704-6.

3 Aho K, Ahvonen P, Lassus A. Sievers K. Tiilikainen A. HLA27 in reactive arthritis: a study of yersinia arthritis and Reiter's disease. Arthritis Rheum 1974: 17: 521-6.

4 Rosenbaum J T. Why HLA-B27: an analysis based on two animal models. Ann Intern Med 1981; 94: 261-3.

5 Leirisalo M, Repo H. Tiilikainen A, Kosunen T U, Laitinen O. Chemotaxis in yersinia arthritis. Arthritis Rheum 1980; 23: 1036-44.

6 Koivuranta-Vaara P, Repo H, Leirisalo M, Kiistala U, Osterman T, Vapaatalo $M$. Enhanced neutrophil migration in vivo in HLA-B27 positive subjects. Ann Rheum Dis 1984; 43: 181-3.

7 Laitinen O, Leirisalo M. Skylv G. Relation between HLA-B27 and clinical features in patients with yersinia arthritis. Arthritis Rheum 1977; 20: 1121-4.

8 Leirisalo M. Skylv G, Kousa M, et al. Followup study on patients with Reiter's disease and reactive arthritis, with special reference to HLA-B27. Arthritis Rheum 1982; 25: 249-59.

9 Repo H, Leirisalo M. Tiilikainen A. Laitinen O. Chemotaxis in yersinia arthritis. In vitro stimulation of neutrophil migration by HLA-B27 positive and negative sera. Arthritis Rheum 1982; 25: 655-61.

10 Repo H, Leirisalo M. Koivuranta P. et al. Neutrophil function and HLA-B27. Br J Rheumatol 1983; 22 (suppl 2): 168-71.

11 Ahvonen P. Sicvers K. Aho K. Arthritis associated with Yersinia enterocolitica infection. Acta Rheumatologica Scandinavica 1969; 15: 232-53.

12 Awdeh Z L. Alper C A. Inherited structural polymorphism of the fourth component of human complement. Proc Natl Acad Sci USA 1980; 77: 3576-80.

13 Alper C A, Boenisch T, Watson L. Genetic polymorphism in human beta-glycoprotein. J Exp Med 1972; 135: 68-80.

14 Mauff G, Alper C A. Awdeh Z, et al. Statement on the nomenclature of human C4 allotypes. Immunobiology 1983; 164: 184-91.

15 Rittner C, Mauff G. C4 polymorphism. In: Albert E D, Baur M P, Mayr W R. eds. Histocompatibility testing 1984. Berlin Heidelberg: Springer, 1984: 318-24.

16 Mayer M M. Complement and complement fixation. In Kabat and Mayer's experimental immunochemistry. Springfield, Illinois: Thomas, 1969: 149-54.

17 Hugli T E, Chenoweth D E. Techniques and significance of C3a and C5a measurement. In: Nakamura R M, Dito W R. Tucker III E S, eds. Laboratory and research methods in biology and medicine. New York: Alan R Liss, 1980: 443-60. 
18 Perrin L H, Lambert $\mathrm{P} \mathrm{H}$, Miescher P A. Complement breakdown products in plasma from patients with systemic lupus erythematosus and patients with membranoproliferative or other glomerulonephritis. J Clin Invest 1975; 56: 165-76.

19 Schenkein H A, Ruddy S. The role of immunoglobulins in alternative complement pathway activation by zymosan. $J$ Immunol 1981; 126: 7-15.

20 Tertti R, Eerola E, Lehtonen O P. Ståhlberg T H, Viander M, Toivanen A. Virulence-plasmid is associated with the inhibition of opsonization in Yersinia enterocolitica and Yersinia pseudotuberculosis. Clin Exp Immunol 1987; 68: 266-74.

21 Hugli T E. Structure and function of the anaphylatoxins. Springer Semin Immunopathol 1984; 7: 193-219.

22 Chenoweth D E, Hugli T E. Demonstration of specific C5a receptor on intact human polymorphonuclear lcukocytes. Proc Natl Acad Sci USA 1978; 75: 3943-7.
23 O'Flaherty J T, Kreutzer D L, Ward P A. Neutroph aggregation and swelling induced by chemotactic agents. Immunol 1977: 119: 232-9.

24 Ward P A, Newman L J. A neutrophil chemotactic factor frore human C5. J Immunol 1969; 102: 93-100.

25 Babior $\mathrm{B} \mathrm{M}$. The role of active oxygen in microbial killing b phagocytes. In: Autor A P, ed. Pathology of oxygen. New York: Raven Press. 1982: 45-56.

26 Wright D G. The neutrophil as a secretory organ of host defensc. In: Gallin J I. Fauci A S, eds. Advances in host defensक mechanisms. New York: Raven Press. 1982: 75-110.

27 Wedmore C V. Williams T J. Control of vascular permeability by polymorphonuclear leucocytes in inflammation. Naturg 1981; 289: 646-50.

28 Terasaki P I, Mickey M R. HL-A haplotypes of 32 diseases Transplantation Reviews 1975; 22: 105-9. 